\title{
Fünfzig Jahre Anstrengung für hundert Jahre Föderation
}

\section{Gerd Leutenecker, Wehr}

Am 1. Januar 2001 versammelten sich zigtausend Menschen in Australien, um das Einhundertjährige Bestehen des Bundesstaates Australien zu feiern. Hundert Jahre zuvor war es ein ähnlich imposantes Feiern, als der Neubeginn Australiens gefeiert wurde. Sechs unabhängige Kolonien schlossen sich zu einem "föderalen Staatenbund" zusammen. Die Arbeit von Jahrzehnten fand einen Schlusspunkt der gleichzeitig der Startpunkt für die gemeinsame Zukunft werden sollte.

Die Australier haben aber lange Jahre ihre Gründungsväter vergessen. Canberra ist das Symbol für den Australischen Staatenbund. Wenn man sich in der Bundeshauptstadt Canberra umschaut, so fällt einem auf, dass die einzelnen Stadtteile zwar auch Namen von berühmten australischen Staatsmänner haben, diese aber im Grunde politische Personen des 20. Jahrhunderts waren, indem sie Staatsämter inne hatten. Weitgehend gleich verhält es sich bei der Namensgebung der australischen Wahlkreise. Der größte Wahlkreis in New South Wales, der sich von Broken Hill bis Dubbo und hin zur Grenze mit Queensland erstreckt, trägt den Namen Parkes. Damit ist zumindest im Outback Henry Parkes, landläufig als der Gründungsvater der Föderation bezeichnet, verewigt.

Australien hat sich vornehmlich auf das 20. Jahrhundert konzentriert. Ihr Jahrhundert, das die identitätsstiftenden Momente für das australische Verständnis liefert. Als wäre keine Vorgeschichte gewesen, schwankte die Aufarbeitung zwischen dem Scham der Sträflingskolonien und dem antiquiertem britischen Untertan. Die eigene kulturelle, gesellschaftliche und politische Historie ist vielleicht zeitlich zu nahe gewesen, das man sich dieser vergewissert hätte. Eine Parallele zur amerikanischen Glorifizierung der staatlichen Gründungsphase ist in Australien nicht auszumachen. Auch heute, anlässlich der Einhundertjahrfeiern Commonwealth of Australia ist das Hauptaugenmerk auf die australischen Errungenschaften des 20. Jahrhunderts gerichtet. Es gab dennoch in den Tageszeitungen Sydney Morning Herald und The Age eine lose Folge von Artikeln namhafter Wissenschaftlern zur Vorgeschichte der Föderation; daran ist feststellbar, dass eine Erinnerung an diese bedeutende historische Errungenschaft mehr den Charakter der wissensvermittelnden Funktion inne hat.

Politische Union, Zollunion, Konföderation, Staatenverbund und Staatenbund - in mehr als fünfzig Jahren vor der offiziellen Staatengründung Australiens 1901 sind diese Ziele formuliert, angestrebt aber auch wieder verworfen worden. Was war Australien vor der Abtrennung von Victoria (1851) und Queensland (1859) von der "Mutterkolonie"? Ein nahezu geeinter Kontinent im Verständnis von New South Wales als das Synonym für Australien. Mit weitgehenden politischen Rechte, ausgestattet von Großbritannien, und einer aufstrebenden gesellschaftlichen Elite, die die eigenen Angelegenheiten vor Ort regeln wollte und konnte. Eben zu diesem Zeitpunkt ist der erste Gedanke nachweisbar, der sich Australien als politisches Ganzes konkret vorstellte. 1847 unternahm Earl Grey, der dann aktuelle britische Colonial Secretary, den Versuch und schlug eine General Assembly vor, mit einer wünschenswerten Zentralmacht für Australien als ganzes. Australien war dabei das Synonym für Australasia, also nicht das Festland alleine, sondern mit Tasmanien (Van Diemens Land), Neuseeland und den weiteren kleineren Inseln im Südpazifik, die unter britischem Einfluss standen. Dieser Vorstoß blieb ohne Widerhall, da die zuständigen kolonialen Stellen nicht mit einbezogen waren oder gar für die Ausgestaltung der Idee konsultiert wurden. Die Kolonien wurden im puren britischen Verständnis behandelt. Die Reaktionen darauf waren die emotionale und politische Ablehnung. 1847 war der falsche Zeitpunkt gepaart mit der unzeitgemäßen Vorgehensweise von Seiten des Mutterlandes für eine "federal authority", die von Teilen in Australien bereits gewünscht wurde. Die entwicklungsstrukturell intendierte Abspaltung Victorias und Queensland von N.S.W. kam dennoch hinzu, und damit verschlechterten sich auch die allgemeinen Handelsbedingungen untereinander. Sicherlich, nicht jeder Handel treibende oder 
Politiker sah dies zu dieser Zeit ebenfalls so, aber im Outback wurde man an den Grenzen de fakto zum Fremden, wenn man die Koloniengrenzen überschritt.

Der nächste Schritt war erneut ein reagieren, weniger ein agieren auf zunehmende Probleme im Inneren. Die Binnenwirtschaft hatte ihre Grenzen. Dabei lässt sich eine von Teilen gewünschte Zollunion ausmachen. Erste Vorstöße gehen bis in die 1860er zurück. Diese "commercial federation" sollte nur als Hilfskonstrukt dienen und keine echte staatliche Integration ermöglichen. Diese hauptsächlich ökonomische ordnungspolitische Grundkonstellation aber ist in der zweiten Hälfte des 19. Jahrhunderts nicht zu unterschätzen. Das Miteinander wirtschaften war nicht eine Wunschvorstellung weniger sondern entsprach der Notwendigkeit auf dem australischen Kontinent. Die regelmäßig stattfindenden "intercolonial conferences" der Premiers, hatten natürlich auch die Koordinierung gemeinsamer Politikfelder zum Inhalt. Man traf sich zwischen 1860 und 1900 im Durchschnitt zwei mal pro Jahr. Hier wurden bereits die gegensätzlichen Auffassungen aber auch die gemeinsamen australischen Notwendigkeiten debattiert. Die Grenzen des uniert Machbaren in den vorgegebenen Rahmen traten erkennbar zu Tage. Von Quarantänebestimmungen, gemeinsame Kommunikationswege (Telegraphenleitung) bis hin $\mathrm{zu}$ problematischsten Kontroversen der Handelsbestimmungen, die Themen für den Föderalstaat Australien waren vorgegeben. Im weitläufigen Areal der Riverina (geographisch, nicht der heutige politisch determinierte kleinere Teil) mit ihren Flüssen und der Zugverbindung, traten die Probleme und Rivalitäten des grenzüberschreitenden Handels in vielfältiger Weise zu Tage.

Ein Fakt aber ist, dass bis in die 80er Jahre des 19. Jahrhunderts alle australische Kolonien vorrangig daran interessiert waren, ihre eigene staatlichen Institutionen und die in vorgegebenen Grenzen souveräne Regierungsfähigkeit auszubauen. Diese eigenständige Orientierung lies nur wenig Platz in der Tagespolitik für den Gedanken und das Handeln für die Föderation.

Gesellschaftlich sind in diesem Zeitraum zwei gegenläufig auszumachende Phänomene feststellbar: Einerseits die starke Identifikation mit der eigenen Kolonie und andererseits in gewisser Weise auch die gekeimte gemeinsame australische Identität. Die ersten Generationen von in Australien geborenen etablierten sich. Zwischen Koloniennationalismus und britischem Subjekt reifte das 'mateship'. Hier findet man auch den nächsten Schritt zur Föderation: die Australian Natives' Association. 1871 gegründet entsprach sie dem Zeitgeist. Nur Männer, die in Australien geboren waren, konnten Mitglieder werden. Allgemein wird sie als eine Verbindung der Arbeitnehmerschaft charakterisiert, die das Anliegen der Föderation propagierte. Ihre Struktur war bereits über die Koloniengrenzen hinweg angelegt, so konnte sie sich an der gesellschaftlichen Verankerung des Ziels einer Nation intensiv beteiligen. Die Australian Natives' Association propagierte den Bundesstaat. Die Materie kam raus aus den Parlamenten und hin zur populistischen Bewegung.

Wieder im politischen System gründete sich der Federal Council of Australasia. Dies ist das erste staatlich institutionalisierte Bindeglied, das das Ziel einer australischen Union erörterte. Das Ziel war eine australische Stimme in Großbritannien zu haben, um ein größeres Augenmerk auf die regionale bzw. geostrategischen Belange zu erzeugen. Die Legislativmacht über eine gemeinsame Außenpolitik war dem Gesetz her da. Aber, da die Initiative von Victoria ausging, nahmen New South Wales und South Australia daran nicht teil. In der Person des Premiers von N.S.W., Henry Parkes, sind die Gründe dafür zu suchen. Er strebte bereits zu diesem Zeitpunkt eine bundesstaatliche Lösung mit legislativer und exekutiver Kompetenz an. Im Grunde genommen war mit dem Federal Council of Australasia von britischer Seite her eine Instanz geschaffen, die eine Legislativmacht über die Angelegenheiten Australiens hatte, aber immer unter der strikten Einbeziehung der einzelnen Kolonialparlamente! Dieses staatlich-institutionelles Ungetüm rekrutierte sich aus den Kolonialexekutiven, nahm hoheitliche Legislativrechte in Anspruch und sollte die eigenen getroffenen Entscheidungen dann wiederum in der eigenen Kolonienlegislative absegnen lassen. Ein anachronistisches System, das aber zumindest ein Versuch wert war.

Außenpolitik hieß Verteidigungspolitik. Und eine gemeinsame Verteidigungspolitik blieb die Klammer für das Zusammenwachsen. Nach 1888, als General Edwards für das britische Colonial 
Office seinen Lagebericht zur Verteidigungsfähigkeit und den notwendigen australischen Anstrengungen verfasst hatte, begann eine neue Runde hin zum Föderalstaat. Henry Parks nahm in seiner berühmten Tenterfield-Rede die Argumente von General Edwards auf und führte dies hin zur Notwendigkeit einer neuen "intercolonial convention" und auf dem Wege der Ausarbeitung einer australischen Verfassung das Ziel der Föderation zu erreichen.

Die 1890er sind der Wendepunkt in der australischen Föderalismusgeschichte.

Die Australasian Federation Conference traf sich am 6. Februar 1890 in Melbourne, mit dem festen Vorsatz, die Einigung Australiens zu verwirklichen. Der vielzitierte Ausdruck an diesem ersten Tag, summierte die Hauptprobleme: Der "Lion in the Path" stammt von James Service, Premier von Victoria. Er hat es am Eröffnungsbanquet in seiner Rede ausführlich ausgeführt, dass die interkolonialen Zölle noch immer die Föderation zur Strecke bringen könne, daher müsse zuerst der Löwe zur Strecke gebracht werden. Es folgte vom 2.März bis zum 9.April 1891 in Sydney die Ausarbeitung der (ersten) Verfassung für den Bundesstaat Australien. Der Löwe war gebändigt, denn im zukünftig föderal organisierten Australien werde es keine internen Handelszölle mehr geben. Die Delegierten gingen mit diesen Ergebnissen zurück in ihre Kolonien, und sollten die Verfassung in ihren jeweiligen Parlamenten zur Abstimmung bringen. Das Morgenlicht des Bundesstaates Australien schimmerte, kam aber gegen den Nebel noch nicht an. Die Parlamente befassten sich nicht mit der Verfassung, es standen teilweise Neuwahlen an, Regierungswechsel folgten, politische Themenverschiebungen setzten ein und die allgemeinen politischen Rahmenbedingungen änderten sich; eine schwere Depression überzog die australischen Kolonien, mit einziger Ausnahme von Western Australia, das durch seine neuen Goldfeldern wirtschaftlich aufblühte. Dringend notwendige soziale Reformen waren die unaufschiebbaren Themen in den Parlamenten, nicht die Föderation.

Mit den staatlichen Instanzen war zu diesem Moment kein glückliches Gelingen möglich. Abermals setzte eine populistische Bewegung ein: Auf der Corowa Conference vom 31. Juli bis 1. August 1893 trafen sich Vertreter der Australian Natives' Association mit der Federation Leagues, die zu diesem Zeitpunkt die Interessensvertretung für die Handeltreibenden und die Farmer war. Eine eher unscheinbare Resolution von John Quick eingebracht, markierte das weitere Vorgehen. Es müsse im Prozess der Föderation verstärkt auf die Einbeziehung des Volkes wert gelegt werden, die Direktwahl der Delegierten und eine Referendumsentscheidung über die neu auszuarbeitenden Verfassung müsse abgehalten werden bevor sie den Parlamenten vorgelegt werde. Etwas absolut neues also. Der Wähler sollte die legitime Adresse sein und damit die direkte Legitimation der neuen Verfassung vom Volke ausgehen. Revolutionär in anderen Teilen der damaligen Welt. Der neue Premier von N.S.W. George Reid fand Gefallen an dieser strukturellen Vorgehensweise. Auf der Premiers' Konferenz im Hobart 1895 einigte man sich dem Sinn der Resolution nach, auf die neue Struktur.

1895 begann die letzte Runde im Ringen um den Staatenbund Australien. Den Vorstellung von Quick folgend, sollte ein erneuter Anlauf für eine "constitutional convention" gestartet werden. Es lag in den Händen der Premiers, die den legislativen Weg bereiten sollten, dass Delegierte gewählt werden sollten. Western Australia stellte die Ausnahme dar, hier wurden die Delegierten von den Mitgliedern des Parlamentes bestimmt. In South Australia durften Frauen mitwählen, sie hatten bereits zu diesem Zeitpunkt das Wahlrecht. Das Parlament von Queensland entschied sich mehrheitlich gegen eine Teilnahme, indem es die Volkswahl der Delegierten ablehnet! Und Neuseeland beendete die Teilnahme.

Um einem weiteren Debakel entgegenzutreten, folgte 1896 in Bathurst die sog. People's Federal Convention. Im öffentlichen Bewusstsein war der Einigungsgedanke verankert. Es sollte Druck auf die Regierungen ausgeübt werden, dass die neue Constitutional Convention auch zügig organisiert werde, beginnend mit der Wahl der Delegierten, die im März 1897 dann in vier Kolonien stattfand. 
Das erste Treffen fand in 1897 in Adelaide statt. Die Neue Verfassung wurde ausgearbeitet. Diese wurde an die Parlamente weitergeleitet, um für Änderungswünsche eine breite Basis zu erhalten. Es stellt Bemerkenswerterweise eine doppelte Legitimationsbasis dar: Die Entscheidungen lassen sich immer auf das Volk und seinen Willen zurückführen, sei es für die Parlamentarier aber auch den Delegierten. Die praktikabel größtmögliche Beteiligung des Volkes fand in Australien statt. Keine einsame exekutive Endergebnisse wurden dem mündigen Volk präsentiert - die Mehrheit der Bürger wusste um was es geht. Man traf sich dann 1897 und 1898 zur abschließenden verfassungsgebenden Versammlungen in Melbourne und Sydney. Diese wurde im Anschluss daran dem Volk zur Abstimmung gegeben.

Aber das Referendum von 1898 wurde in N.S.W. ein Fehlschlag. Das hoch gesetzte Quorum wurde nicht erreicht, und wenn die größte und älteste Kolonie sich nicht beteiligen würde, wäre das Ziel der Föderation nicht erreicht. Auf dem Premiers Meeting im Januar 1899 in Melbourne an dem auch Queensland teilnahm, wurden kleine Änderungen vorgenommen wie etwa, dass die zukünftige Bundeshauptstadt näher an Sydney sein müsse. In der zweite Referendumsrunde wurde die Verfassung mehrheitlich angenommen, dieses mal nahm auch Queensland teil, aber eine Entscheidung von Western Australia fehlte noch. 1899 erhielten die Frauen das Wahlrecht in W. A.. Politischer Hintergrund war, dass man die Hoffnung auf die Frauen setzte, dass sie mehrheitlich für die Föderation stimmen würden und damit der fälschlicherweise angenommenen eventuell höheren Anzahl von Gegenstimmen von Seiten der Minenarbeiter entgegenzuwirken. Es war im Grunde nicht mehr das Problem der Wahlbürger, ob man sich zum Bundesstaat zusammenschließen solle, sondern ob man diese Verfassung dafür als geeignet betrachtet! Die Frage nach dem letztendlichen Wahlerfolg für das neue Staatenkonstrukt lässt sich zugespitzt in der Art formulieren, dass eine Mehrheit sich dadurch auch positive Effekte versprach, im individuellen Wohlergehen, speziell aber der wirtschaftlichen Besserstellung.

Der letzte Schritt führte notwendigerweise 1900 nach London. Vier australische Delegierte und ein Beobachter (Western Australia) kamen in London an, um ihr Mandat zu erfüllen, dem parlamentarischen und imperial-hoheitlichen Prozedere in Westminster beizuwohnen. Ein herausragendes Problem für London war, dass das Privy Council immer noch letzte Instanz für australische Gerichte sein müsse. Alfred Deakin war es, der gegen Joseph Chamberlain anging. Sein Argument war, dass die britische Regierung genügend Zeit hatte, sich an der Verfassung zu beteiligen (in der Form von "gewünschten" Änderungen), und das australische Volk bereits darüber abgestimmt hatte. Das Verständnis von Mutterland und Kolonie schimmerte noch immer im gegenseitigen Umgang miteinander durch. Chamberlain konnte nicht zurückweichen und nur seine Kompromissbereitschaft dadurch belegen, das die Regularien der Wege zum letztinstanzlichen Privy Council debattiert wurden. Letztendlich mussten die vier Delegierten diesen britischen Entschluss aber akzeptieren. Am 14. Mai wurde der Gesetzesvorschlag in das House of Commons eingebracht. Das "Commonwealth of Australia Bill" wurde im Juli verabschiedet, und Königin Victoria gab am 9. Juli 1900 ihre Zustimmung.

Zurück in Australien ging die Föderation ihren Weg. Der neu eingetroffene erste GeneralGouverneur, Lord Hopetoun, hatte die ihm zugedachte Aufgabe, den ersten Prime Minister zu ernennen. Und in Verkennung der Persönlichkeiten, nominierte er William Lyne, in diesem Moment gerade Premier von N.S.W., indessen gleichzeitig auch ein bekennender Gegner der Föderation. Keiner wollte und konnte mit ihm zusammenarbeiten und er gab selber den Weg frei für Edmund Barton. Die Inaugurationsfeiern konnten mit einem amtierenden und respektierten Prime Minister of Australia am 1. Januar 1901 stattfinden.

Die fünf wesentlichen Strukturmerkmal der australischen Föderation sind demnach: 1. eine geschriebene Verfassung mit doppelter Gewaltenteilung, die durch gewählte Delegierte ausgearbeitet wurde; 2. eine Volksabstimmung, um eine größtmögliche Legitimierung für den Staat zu erhalten; 3. der neue Staat hat durch die Kolonialparlamente die legislative Weihen erfahren, so dass konstatiert werden kann, die Kolonien haben bei der Beschneidung ihrer Rechte mitgewirkt; 4. 
die staatsrechtlich unentbehrliche Anerkennung durch das britische Parlament was sozusagen die zweite Legislativweihung war, und 5. die königliche Billigung.

Der australische Staatenbund ist nicht alleinig als Föderation ohne seine Verfassungsentwicklung erklärbar, so wie die Verfassung nicht alleinig erklärbar ist ohne Föderation. Die Intention sich zusammenzuschließen über den Weg der Föderation mit vertragsrechtlichem Konstrukt war nicht neu, Australien konnte bereits in den 1890er auf fünf Staaten in der Welt blicken, die diesen Weg gegangen sind. Der langatmige Weg hätte nicht ohne den Willen des Volkes so zum Erfolg gebracht werden können, als einzelnen Politikern zeitweilig die Luft ausgegangen ist, und die Bewegung hin zur Föderation vom Volke ausging. Ein durch und durch demokratisch gesinntes Empfinden, trotz mehrheitlich rassistischer Grundhaltung. Ein Makel, der Australien noch lange anhaftete.

Ein Auswahl von weiterführender Literatur ohne Zeitschriftenartikel. Stichworte: Föderation, Staatengründung, Verfassungs"väter", politisch-historische Relevanz.

\section{Zeitgenössische Literatur und Quellen}

Allin, C.D., 1907. Early federation movement in Australia. Kingston, Ontario

Anderson, H., Hsg., 1991. Tocsin: Radical arguments against federation 1897-1900, Melbourne Australasian Federal Convention: Official record of the debates of the Australasian Federal Convention, Sydney 1986 (Adelaide 1897, Sydney 1897, Melbourne 1898).

Australasian Federation League, 1894-95. The Commonwealth, Journal of the Australasian Federation League in NSW.

Australasian Federation League, (April-September) 1898. The Australian federalist, Journal of the Federal Association. [journal established by the Australasian Federal League for the referendum]

Australasian Federation League, 1898. The Federalist, Journal of the Tasmanian branch of the Federal Association.

Australia, 1893. Federation Conference, Official Report of the Federation Conference held in the Court House, Corowa, on Monday 31 st July and Tuesday 1st August 1893, Corowa.

Baker, Sir R, 1897. The executive in a Federation, Adelaide.

Baker, Sir R, 1897. Federation, Adelaide.

Baker, Sir R, 1891. A manual of reference to authorities for the use of the members of the National Australasian Convention, Adelaide.

Bendigo League: The new federation movement: the Corowa Federation Conference, report of the Bendigo delegates, submitted to the Sandhurst branch of the Australian Natives' Association, in: The new federation movement, from the Corowa Conference, 1 August 1893, to the ANA Conference, 27 March 1894, Bendigo.

Clark, A., 1900. The federal financial problem and its solution, Hobart.

Clark, A., 1901. Studies in Australian constitutional law, Melbourne.

Clark, C. M. H., 1955. Select documents in Australian history 1851-1900, Sydney.

Crichton, P., P. Hardy, M. Stell, 1992. Federation bibliography, Canberra.

Dalley, W., 1884. Speeches on the proposed Federal Council of Australasia and the resolutions of the Convention, Sydney.

Deakin, A., 1963. The federal story: The inner history of the federal cause 1880-1900, Carlton.

Deakin, A., 1995. And be one people: Alfred Deakin's federal story, introduced by Stuart Macintyre, Carlton.

Dilke, C., (June) 1891. The Commonwealth of Australia, The Forum 11.

Drake, J., 1896. Federation: Imperial or democratic?, Brisbane 1896.

Fraser, J., 1910. Australia: The making of a nation, London.

Garran, R., 1897. The coming Commonwealth, Sydney. 
Garran, R., 1958. Prosper the Commonwealth, Sydney.

Gay, W., M. Sampson, 1895. The Commonwealth and the Empire, o.O.

Griffith, S., 1899. Australian federation and the draft Commonwealth Bill, Brisbane.

Griffith, S., 1896. Some conditions of Australian federation, Brisbane.

Hughes, W.M., W. Dick, 1897. Federation as proposed by the Adelaide Convention, Adelaide.

James, W., 1949. The James papers: letters on federalism, Australian Quarterly 21(4).

Keenan, J., 1904. The inaugural celebrations of the Commonwealth of Australia, Sydney.

Kingston, C., (February) 1896. The democratic element in Australian federalism, Review of Reviews.

O'Sullivan, E.W., 1900. From colony to Commonwealth, Sydney.

Parkes, H., 1895. Speech on the policy of the Reid Ministry as opposed to federation delivered in the Legislative Assembly, 30 May 1895, Parramatta.

Parkes, H., 1892. Fifty years in the making of Australian history, London.

Parkes, H., 1891. One people, one destiny: Speech of the Hon. Sir Henry Parkes, GCMG, to the Citizens of Sydney, in the Gaiety Theatre, Saturday, 13 June 1891, Sydney.

Parkes, H., 1890. The federal government of Australasia: Speeches delivered on various occasions (November 1888-May 1890), Sydney.

Perkins, E., D. Headon, Hsg., 1997. Our first republicans: Selected writings of John Dunmore Lang, Charles Harpur and Daniel Henry Deniehy 1840-70, Sydney.

Quick, J., R.R. Garran, 1901. The annotated constitution of the Australian Commonwealth, Sydney.

Quick, J., 1965. Sir John Quick's notebook, hsg. v. Fredman, L., Newcastle.

Reid, G., 1917. My reminiscences, London.

Robertson, A., 1897. Federation and afterwards: A fragment of history, Sydney.

Tomm, L., (August) 1897. The referendum in Australia and New Zealand, Contemporary Review.

Wise, B.R., 1913. The making of the Australian Commonwealth 1889-1900, London.

\section{Monographien und Sammelbände}

Alomes, Stephen, 1988. A nation at last?: the changing character of Australian nationalism 18801988, North Ryde.

Anderson, Margaret, 1998. When Australia was a woman: images of a nation, Perth.

Scott, Ernest, hsg., 1988. The Cambridge history of the British Empire. [Australia, vol. 7, 425-453], Cambridge.

Garran, R., 1997. The Federation Movement and the founding of the Commonwealth Australia: The constitution makers. (= Papers on Parliament Nr. 30). Canberra: Department of the Senate.

Australian dictionary of biography, 1966. Carlton.

Aveling, M., 1970. A history of the Australian Natives' Association 1871-1900, Monash.

Bannon, J., 1994. The crucial colony: South Australia's role in reviving federation 1891 to 1897, Canberra.

Bennett, S., Hsg., 1975. Federation, Melbourne.

Bennett, S., 1971. The making of the Commonwealth, Melbourne.

Birrell, Robert, 1995. A nation of our own: citizenship and nation-building in federation, Melbourne.

Bunbury, Bill, 1998. Unfinished business: reconciliation, the republic and the constitution, Sydney.

Chesterman, John, Brian Galligan, 1997. Citizens without rights: Aborigines and Australian citizenship, Cambridge.

Clark, C.M.H., 1981. A history of Australia, vol. 5 (The people make laws, 1888 - 1915), Carlton. 
Craven, G., Hsg., 1992. Australian federation: Towards the second century, Carlton.

Craven, G., 1986. The Convention debates 1891-1898: Commentaries, indices and guide, Sydney.

Crisp, L.F, 1990. Federation fathers. Carlton.

Crowley, F., Hsg., 1974. A new history of Australia, Melbourne.

Cunneen, C., 1983. King's men: Australia's Governors-General from Hopetoun to Isaacs, Sydney.

Davidson, A., 1991. The invisible state: The formation of the Australian state 1788- 1901, Melbourne.

Dermody, K., 1997. A nation at last: The story of federation, Canberra.

Ely, Richard, 1976. Unto God and Caesar: religious issues in the emerging Commonwealth, 1891-1906, Carlton.

Evans, R., C. Moore, K. Saunders, B. Jamison, B., 1997. 1901: Our future's past: Documenting Australia's federation, Sydney.

Fitzhardinge, L., 1964. That fiery particle: William Morris Hughes, a political biography, vol. 1, 1862-1914, Sydney.

Gabay, A., 1992. The mystic life of Alfred Deakin, New York.

Glass, M., 1997. Charles Cameron Kingston, Carlton.

Graham, A.D., 1939. The life of the Right Honourable Sir Samuel Walker Griffith, Brisbane.

Grimshaw, P., M. Lake, A. McGrath, M. Quartly, 1994. Creating a nation, Melbourne.

Greenwood, G., Hsg., 1997. Australia: a social and political history. London.

Haward, M., J. Warden, Hsg., 1995. An Australian democrat: The life, work and consequences of Andrew Inglis Clark, Hobart.

Hirst, J.B., 1998. Discovering democracy: a guide to government and law in Australia, Carlton South.

Hodgins, Bruce W., Don Wright, W.H. Heick, Hsg., 1978. Federalism in Canada and Australia: The early years, Canberra.

Irving, Helen, Hsg., 1999. The Centenary companion to Australian federation, Cambridge, Melbourne.

Irving, Helen, 1997. To constitute a nation: A cultural history of Australia's constitution, Melbourne.

Irving, Helen, 1996. A woman's constitution?: Gender and history in the Australian Commonwealth, Sydney.

La Nauze, J. A., 1972. The making of the Australian constitution, Carlton.

Livingston, K. T., 1996. The wired nation continent: the communication revolution and federating Australia, Melbourne.

Martin, A., 1908. Henry Parkes: A biography, Carlton.

Macintyre, S., 1986. The Oxford history of Australia, vol. 4, The succeeding age: 1901-1942, Melbourne.

Margarey, S., S. Rowley, S. Sheridan, 1993. Debutante nation: Feminism contests the 1890s, Sydney.

McKenna, Mark, 1996. The captive republic: a history of republicanism in Australia 1788-1996, Cambridge.

McMinn, W.G., 1994. Nationalism and federalism in Australia, Melbourne.

McMinn, W.G., 1989. George Reid, Carlton.

McMinn, W.G., 1979. A constitutional history of Australia, Melbourne.

McMullin, R., 1991. The light on the hill: The Australian Labor Party 1891-1991, Melbourne. 
Martin, A.W., Hsg., 1969. Essays in Australian federation, Melbourne.

Matthews, Brian, 1999. Federation, Melbourne.

Norris, Ronald, 1975. The emergent Commonwealth: Australian federation, expectations and fulfilment 1889-1910, Carlton.

O'Collins, G., Patric. McMahon, 1965. A founder of Australian federation, Carlton.

Reynolds, J., 1984. Edmund Barton, Sydney.

Rickard, J., 1976. Class and politics: New South Wales, Victoria and the early Commonwealth 1890-1910, Canberra.

Russell, Roslyn, Philip Chubb, 1998. One destiny!: The federation story, how Australia became a nation, Ringwood.

Saunders, C., 1989. The Constitutional framework: Hybrid, derivative but Australian, Melbourne.

Souter, Gavin, 1976. Lion and kangaroo: the initiation of Australia, 1901-1919, Sydney.

Trainor, Luke, 1994. British imperialism and Australian nationalism: manipulation, conflict, and compromise in the late nineteenth century, Cambridge.

Ward, J.M., 1958. Earl Grey and the Australian Colonies, 1846-1857: A study of self-government and self-interest, Carlton.

White, R., 1981. Inventing Australia: Images and identity 1688-1980, Sydney.

Wicks, B. M., 1997. Understanding the Australian constitution: The plain words, Sandy Bay.

Williams, J., 1995. In search of the Federal Citizen: Andrew Inglis Clark and the 14th Amendment, Canberra. 